\title{
The Capitalization Rate of Commercial Properties and Market Returns ${ }^{+}$
}

\section{$\frac{\text { G. Donald Jud }}{\text { Daniel T Winkler }}$ *}

\begin{abstract}
This study develops a model of real estate cap rates that draws on the weighted average cost of capital (WACC) theory and the capital asset pricing model (CAPM) in the finance literature. The model indicates cap rates are determined by debt and equity spreads. The debt spread is the risky debt rate less the risk-free rate, and the equity spread is the return on the market less the risk-free rate. The empirical results support the importance of both spreads; however, cap rates respond with significant adjustment lags to changes in capital market spreads. Our findings support the widely held belief that real estate markets are information inefficient and segmented from the national capital market.
\end{abstract}

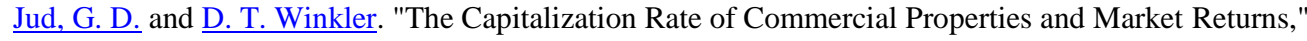
Journal of Real Estate Research, vol. 10, no. 5, 1995, pp. 509-518.

Made available courtesy of American Real Estate Society

\section{Introduction}

The capitalization (cap) rate as used in the real estate literature refers to the ratio of net operating income to property value. This rate has a particularly important role in property valuation, because the income capitalization method converts the expected income stream from commercial property into an estimate of asset value by dividing the net operating income stream by the capitalization rate (Brueggeman and Fisher, 1993: 438).

The cap rate bears a close relation to the weighted average cost of capital (WACC) as defined in the corporate finance literature (Copeland and Weston, 1988). The WACC is the rate of discount that reflects the average costs of debt and equity capital employed by a firm. Discounting the cash flows from corporate assets at the WACC reveals the value of the firm. The relation between the WACC and firm valuation has extensive theoretical underpinnings extending from the firm valuation work of Modigliani and Miller (1958). Sharpe's (1964) development of the capital asset pricing model (CAPM) revolutionized stock portfolio theory and provided a widely accepted method to empirically estimate the cost of equity, which as this paper shows is an embedded component in the cap rate.

Recent empirical work in the real estate literature seeks to explain the cap rate relative to other rates and macroeconomic factors (Froland, 1987; Evans, 1990). Ambrose and Nourse (1993) develop an investment approach based on the WACC; however, they do not incorporate the CAPM in their model. Instead, they rely on the intuitive argument that debt rates on mortgages should be related to government debt rates and that the cap rate should be related to the earnings-price ratio.

'The RREEF Funds 1995 manuscript prize winner for Best Paper on Real Estate Investment/Portfolio Management presented at the American Real Estate Society annual meeting.

*Finance Department, Bryan School of Business and Economics, University of North Carolina at Greensboro, Greensboro, North Carolina 27412-5001. 
Our study draws on the theoretical underpinnings of the WACC and the CAPM models in the corporate finance and investment literature to develop a theoretic model of the capitalization rate for real estate properties. Recognizing the imperfect market conditions inherent with real estate transactions, we use a lag component process for market variables as suggested by Evans (1990). The resulting empirical model explains a substantial portion of the variation in cap rates.

\section{Literature Review}

Early research by Ricks (1969) and Sirmans and Webb $(1978,1980)$ estimated imputed equity yields, variances and tax rates. These studies assumed various holding periods and no appreciation in price. Fisher, Lentz and Stern (1984) and Nourse (1987) investigated the effects of income tax changes on income property using data from the American Council on Life Insurance (ACLI). These studies examined the effect on cap rates brought about by major tax law changes. Fisher, Lentz and Stern (FLS) found that the 1976 tax law, which required amortization of construction taxes and interest (effectively increasing construction costs), raised the cap rate for new properties, while leaving existing property cap rates unchanged. The 1981 tax law change increased allowable depreciation, which decreased the cap rate for both new and existing properties. Nourse (1987), reexamining the FLS study, reported no change in cap rates for the 1976 tax law change and a much smaller decrease in cap rates for the 1981 tax law change.

Guntermann and Smith (1987) derived estimates of equity rates and costs of capital for property REITs, mortgage REITs, and homebuilders/developers. While operating properties and REITs had a before-tax cost of capital of $16.6 \%$, homebuilders/ developers' cost of capital was substantially greater at $34.9 \%$. Their study concluded that the data sources and procedures permit the estimation of cost of capital and equity rates with satisfactory precision and reliability for the majority of investment or appraisal applications.

Froland (1987) compared cap rate movements with competitive yields in the asset trading markets using quarterly cap rates for apartments, retail, office, and industrial properties for the first quarter of 1970 through the second quarter of 1986. He found particularly strong correlations of the cap rate with mortgage rates, ten-year bond rates, and the earnings/price ratio. In addition, inflationary expectations as measured by the Treasury bond-bill spread were inversely related to cap rates. Froland also reported negative correlations between cap rates and indicators of economic cycles, including capacity utilization, national vacancy rate, and the percentage change in real GNP. Using a stepwise regression approach, between $86 \%$ and $95 \%$ of the variation in cap rates was explained by the mortgage rate, the eight-quarter bond-bill spread, and the price- earnings ratio. Froland's empirical results were not bound through a theoretical framework and no tests or corrections for autocorrelation appeared in the study.

A study by Evans (1990) noted the sensitivity of the multifamily and nonresidential real estate cap rates to the earnings/price ratio in the stock market. This study of quarterly cap rates for 1966-1988 reported a strong positive relation of real estate cap rates lagging the earnings/price ratio by one period. Although short of statistical significance, a somewhat lesser positive correlation occurred in the same quarter and a negative correlation occurred in the second quarter. Evans concluded that these results were not consistent with the theory that real estate markets are information efficient. 
Ambrose and Nourse (1993) examined mean quarterly capitalization rates for commercial/retail, office buildings, commercial services, industrial, and hotel properties for 1966 through 1988. The theoretical base for their study is the traditional WACC model that has been used so extensively in the finance literature. Their empirical model related cap rates to a local variable, the spread between long-term and short-term government bond rates, the earnings/price ratio of the S\&P 500, and debt-to-equity components. The debt-to-equity components were estimated from the average loan-tovalue and property mortgage costs. Using seemingly unrelated regression (SUR), they reported that cap rates were not closely tied to either the S\&P 500 or the bond risk premium spread. Using a cross-sectional/time-series regression approach, they found a weighted cost of debt of .98 , not significantly different from one. Also, the return on equity was estimated at $4.85 \%$ and was statistically different from zero. The intercept and slope coefficients were found to vary significantly by property type; however, the panel data regression did not permit separate slope coefficients by area.

Our study extends previous work by Nourse (1987) by developing a theoretical model consistent with the WACC and CAPM. Unlike other studies that have used the ACLI database, our study uses National Real Estate Index panel data for office, warehouse/distribution, retail, and apartment properties. These data consist of twentyone MSAs for fifteen half-year periods starting in the second half of 1985. The empirical model uses a one factor (location) fixed-effects model with correction for autocorrelation for each location fixed effect. Consistent with Evans (1990), we include one- and two- period lags for market variables. Also, separate results are reported for each property type, permitting separate slope estimation for each variable while retaining the benefits of panel data.

\section{A Theory of Cap Rates}

The cap rate $(\boldsymbol{R})$ equals first year (expected) net operating income $\mathbf{N O I}$ divided by the value of the propertv ( V) as follows (Ellwood. 1970):

$$
R=\frac{N O I_{1}}{V} \text {. }
$$

The property value for determining the cap rate is based on the sales price in a competitive market commonly called the market value. Similarly, the WACC is equal to the net operating income divided by the market value of the firm (Modigliani and Miller, 1958), which is identical to equation (1).

Brueggeman and Fisher (1993) note that the cap rate (from equation 1) is not an internal rate of return on investment (IRR) because it does not consider changes in projected future income (or changes in the value of a property over time because of changes in the income stream). If the income stream is expected to grow at a constant growth rate $(g)$ into the foreseeable future, Brueggeman and Fisher (1993) show that the value of a property is estimated as the present value of a perpetual stream of future net operating income cash flows using discount rate $r$ :

$$
V=\frac{N O I_{1}}{r-g} .
$$


Rearranging equation (2), the cap rate equals the total required return on the property less the expected growth rate as given:

$$
R=r-g=\frac{N O I_{1}}{V}
$$

In a traditional framework, the WACC is the overall (or average) cost of capital. The WACC equation equals the market value of debt $(L)$ divided by the firm's value $(V)$ multiplied by the debt cost $\left(r_{D}\right)$ plus the cost of equity $\left(r_{E}\right)$ weighted by the equity-value ratio as given:

$$
W A C C=\frac{L}{V} \cdot r_{D}+\left(1-\frac{L}{V}\right) \cdot r_{E}
$$

The tax rate is not included in equation (4) because the analysis is on a pre-tax basis.

The WACC is the required rate of return on projects having the same risk as the firm, therefore, for such projects, it is the hurdle rate that must be met for projects to be considered acceptable according to the net present value criterion. The WACC as defined in equation (4) is equivalent to ( $r$ ) defined in equation (3). ${ }^{1}$ Equation (4) is derived from a CAPM framework, but it is identical to the Modigliani and Miller definition (Copeland and Weston, 1988: 456).

To arrive at the cap rate $(R)$, note that $r=R+g$ from equation (3). Substituting this expression for the WACC in equation (4) and rearranging, results in equation (5) as follows:

$$
R=\frac{L}{V} \cdot r_{D}+\left(1-\frac{L}{V}\right) \cdot r_{E}-g
$$

Using the CAPM relationship, where $r_{F}$ and $r_{M}$ denote the risk-free interest rate and market return, respectively, the expected return on equity (or the cost of equity), $E\left(r_{E}\right)$, is:

$$
E\left(r_{E}\right)=r_{F}+\left(E\left(r_{M}\right)-r_{F}\right) *\left[\operatorname{COV}\left(r_{E}, r_{M}\right) / \sigma_{M}^{2}\right]
$$

Substituting the expression for $E\left(r_{E}\right)$ from equation (6) for $r_{E}$ in equation (5) and rearranging, the cap rate relationship is:

$$
R=r_{F}+\frac{L}{V}\left(r_{D}-r_{F}\right)+\left(1-\frac{L}{V}\right)\left[E\left(r_{M}\right)-r_{F}\right]\left[\frac{\operatorname{COV}\left(r_{E}, r_{M}\right)}{\sigma_{M}^{2}}\right]-g .
$$

Arranging equation (7) in excess return form for empirical testing and substituting for the equity beta, where $\beta=\operatorname{COV}\left(r_{E}, r_{M}\right) / \sigma_{M}^{2}$, equation (8) is stated as follows:

$$
R-r_{F}=\frac{L}{V}\left(r_{D}-r_{F}\right)+\left(1-\frac{L}{V}\right)\left[E\left(r_{M}\right)-r_{F}\right] \beta-g .
$$


Equation (8) states the excess cap rate return is explained by three terms: (1) the spread between long-term debt and the risk-free rate multiplied by the loan-to-value ratio; (2) one minus the loan-to-value ratio multiplied by the product of the equity return spread and the beta (estimated by the covariance of real estate equity returns with market returns divided by the variance of market returns); and (3) the growth rate in net operating income. Note that even though the growth rate term is a constant in equation (8), different MSAs and different property types are likely to have different growth rates.

The empirical model of equation (8) includes market spread variables as the difference between bonds with a BAA debt rating and the three-month Treasury bill and the total return on the Standard and Poor's 500 index minus the three-month Treasury bill. In addition, the empirical model includes one- and two-period lagged variables for the debt spread and equity spread. These lagged variables capture variation from information from previous periods that subsequently becomes impounded in the cap rate (Evans, 1990). Structural variables are present to control for differences in the cap rate levels for the twenty-one MSAs; these variables capture differences in growth rates for the MSAs. The empirical model relates the excess cap rate (EXCSCAP), as measured by the cap rate minus the annualized three-month Treasury bill rate, to the following independent variahles.

$$
\begin{aligned}
E X C S C A P=\alpha & +\beta_{1} B A A S P R D_{t}+\beta_{2} B A A S P R D_{t-1}+\beta_{3} B A A S P R D_{t-2} \\
& +\beta_{4} S P S P R D_{t}+\beta_{5} S P S P R D_{t-1}+\beta_{6} S_{P S P D} D_{t-2} \\
& +\beta_{7} S T_{M S A}+\varepsilon .
\end{aligned}
$$

where:

$$
\begin{aligned}
\text { BAASPRD }= & \text { the return on BAA-rated debt minus the annualized three- } \\
& \text { month Treasury bill rate; } \\
B A A S P R D_{t-1}= & \text { the return on BAA-rated debt minus the annualized three- } \\
& \text { month Treasury bill rate lagged one period; } \\
B A A S P R D_{t-2}= & \text { the return on BAA-rated debt minus the annualized three- } \\
& \text { month Treasury bill rate lagged two periods; } \\
S P S P R D_{t}= & \text { the total return on the Standard and Poor's } 500 \text { Index } \\
& \text { (annualized) minus the annualized three-month Treasury bill } \\
& \text { rate; } \\
S & \text { the total return on the Standard and Poor's } 500 \text { Index } \\
& \text { (annualized) minus the annualized three-month Treasury bill } \\
& \text { rate lagged one period; } \\
S P P R D_{t-2}= & \text { the total return on the Standard and Poor's } 500 \text { Index } \\
& \text { (annualized) minus the annualized three-month Treasury bill } \\
& \text { rate lagged two periods; } \\
S T_{M S A}= & \text { structural variables in the fixed-effects model for the MSAs; } \\
\varepsilon= & \text { the disturbance term. }
\end{aligned}
$$

Both the debt and equity spread variables are expected to have positive coefficients for period t. ${ }^{2}$ Lagged variable coefficients could have positive or negative signs as corrections to informational inefficiencies in the cap rate markets. 


\section{Data}

The data from market cap rates are obtained from Market History Reports, which is a publication of the National Real Estate Index. This source is published quarterly by Liquidity Fund with Ernst \& Young as editorial advisor. Cap rates are determined from actual net operating income for office, warehouse/distribution, retail, and apartment properties every two quarters from the fourth quarter of 1985 through the fourth quarter of 1992, for a total of fifteen cap rate observations per MSA. Of the twenty-four MSAs reported in the Market History Reports, two markets are excluded from the analysis because data are incomplete for periods prior to 1987, and one other market is excluded because data are only available for one property type. Accordingly, 315 cap rates are available from twenty-one MSAs for each of four property types. Annualized rates of return for bonds and the Standard and Poor's 500 stock index are obtained from the CitiCorp database.

\section{Empirical Results}

As shown in Exhibit 1, cap rates for all property types declined from the last quarter of 1985 to the second quarter of 1989, then increased steadily through the fourth quarter of 1992. Cap rates were highest for warehouse/distribution, followed by retail and apartments until early 1992. Office cap rates were from one-quarter to one-half percent below other property cap rates throughout the entire period. In Exhibit 2, cap rate spreads (or the cap rate minus the annualized three-month Treasury bill rate) range from $2.33 \%$ for office properties to $3.04 \%$ for warehouse/distribution. Spreads between BAA-

\section{Exhibit 1 \\ Cap Rates from 1985-1992}

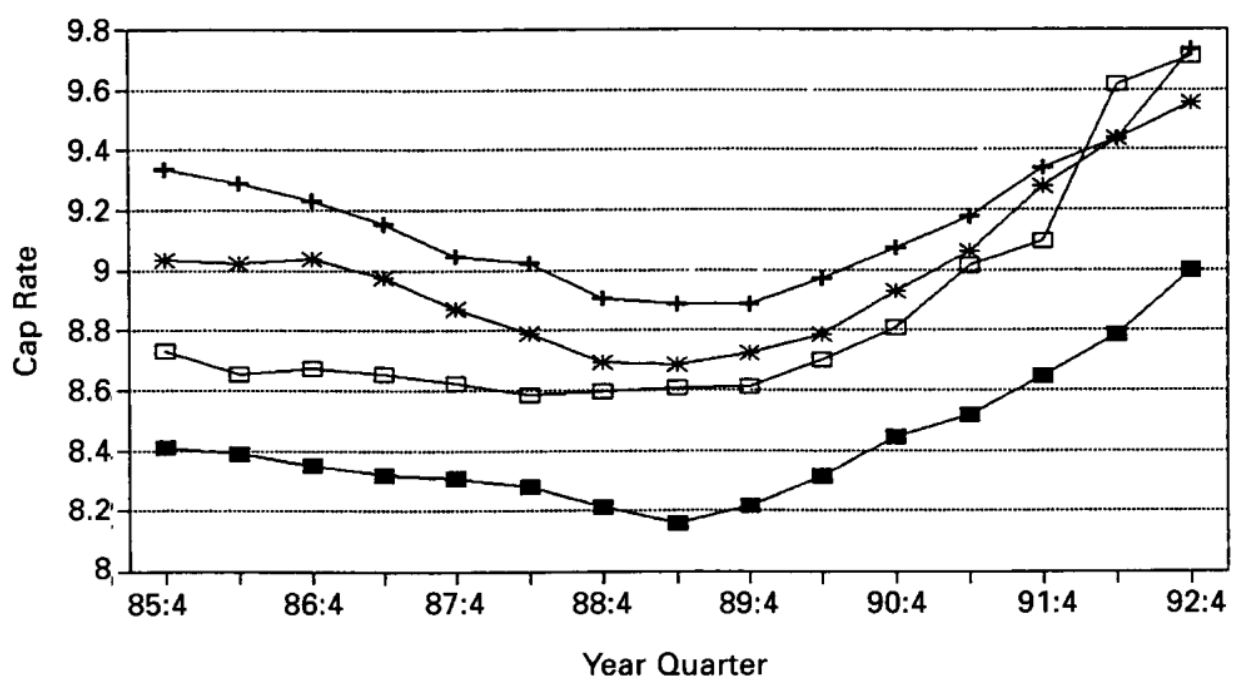

Office -+- Warehouse/Dist. $\quad *$ Retail $\quad \square$ Apartment 


\section{Exhibit 2}

\begin{tabular}{lcccc}
\hline Variable & Mean & Std Dev. & Minimum & Maximum \\
\hline Cap Rate Spread (Office) & 2.33 & 1.92 & -1.90 & 7.30 \\
Cap Rate Spread (Warehouse/Dist.) & 3.04 & 1.81 & -.50 & 7.30 \\
Cap Rate Spread (Retail) & 2.89 & 1.85 & -.80 & 6.80 \\
Cap Rate (Apartment) & 2.77 & 1.94 & -.90 & 7.80 \\
BAASPRD & 4.02 & 1.19 & 2.00 & 5.70 \\
BAASPRD & 3.90 & 1.09 & 2.00 & 5.40 \\
BAASPRD & 3.88 & 1.06 & 2.00 & 5.10 \\
SPSPRD & 6.89 & 17.72 & -25.15 & 36.61 \\
SPSPRD & 9.41 & 19.70 & -25.15 & 39.16 \\
SPSPRD & 9.32 & 19.70 & -25.15 & 39.16 \\
\hline
\end{tabular}

rated bonds and Treasury bills averaged approximately 4\%, while equity spreads ranged from $6.89 \%$ to $9.41 \%$ depending on the lag structure.

The regression results for the four property types are shown in Exhibit 3. The fixed effects regression coefficients for the twenty-one MSAs are not shown in Exhibit 3; however, Chow tests indicate the group effects are significant at the $1 \%$ level for all of the regressions. Thus, our findings confirm that real estate markets are segmented across metropolitan areas.

The regression models shown in Exhibit 3 all are statistically significant at the .01 level. ${ }^{3}$ Preliminary estimates of the models were examined for possible autocorrelation.

\section{Exhibit 3*}

\begin{tabular}{lcccc}
\hline Variable & Office & $\begin{array}{c}\text { Warehouse/ } \\
\text { Distribution }\end{array}$ & Retail & Apartment \\
\hline BAASPRD & 1.409 & 1.390 & 1.438 & 1.525 \\
BAASPRD $D_{t-1}$ & $(21.489)^{\mathrm{a}}$ & $(21.136)^{\mathrm{a}}$ & $(22.462)^{\mathrm{a}}$ & $(19.561)^{\mathrm{a}}$ \\
& $.662 \mathrm{E}-01$ & .115 & $.658 \mathrm{E}-01$ & $-.412 \mathrm{E}-01$ \\
BAASPRD & $(.753)$ & $(1.293)$ & $(.762)$ & $(-.395)$ \\
& -.290 & -.292 & -.283 & -.224 \\
SPSPRD $_{t-2}$ & $(-4.111)^{\mathrm{a}}$ & $(-4.153)^{\mathrm{a}}$ & $(-4.123)^{\mathrm{a}}$ & $(-2.672)^{\mathrm{b}}$ \\
& $.136 \mathrm{E}-01$ & $.155 \mathrm{E}-01$ & $.161 \mathrm{E}-01$ & $.158 \mathrm{E}-01$ \\
SPSPRD $_{t-1}$ & $(5.585)^{\mathrm{a}}$ & $(6.374)^{\mathrm{a}}$ & $(6.795)^{\mathrm{a}}$ & $(5.437)^{\mathrm{a}}$ \\
& $.148 \mathrm{E}-01$ & $.166 \mathrm{E}-01$ & $.174 \mathrm{E}-01$ & $.144 \mathrm{E}-01$ \\
SPSPRD $_{t-2}$ & $(4.972)^{\mathrm{a}}$ & $(5.668)^{\mathrm{a}}$ & $(6.052)^{\mathrm{a}}$ & $(4.059)^{\mathrm{a}}$ \\
& $-.109 \mathrm{E}-02$ & $.257 \mathrm{E}-03$ & $.516 \mathrm{E}-03$ & $-.152 \mathrm{E}-02$ \\
& $(-.529)$ & $(.125)$ & $(.257)$ & $(-.622)$ \\
F-Value & $47.04^{\mathrm{a}}$ & $43.73^{\mathrm{a}}$ & $46.74^{\mathrm{a}}$ & $32.61^{\mathrm{a}}$ \\
Adjusted $R^{2}$ & $82.67 \%$ & $81.57 \%$ & $84.38 \%$ & $76.61 \%$ \\
$N$ & 273 & 273 & 273 & 273 \\
Est Autocorr. & .242 & .208 & .270 & .253 \\
\hline
\end{tabular}

*Fixed effects regression coefficients are not shown for the 21 MSAs. However, Chow test results indicate the group effects are significant at the $.01 \%$ level for all regressions.

Notes: ${ }^{a}$ significant at the $.01 \%$ level; bsignificant at the $1 \%$ level 
The model coefficients shown in Exhibit 3 were estimated using a two-step procedure for a one-way fixed effects model. In the first step, the model was estimated with the purpose of estimating $p$, the autocorrelation coefficient for each MSA. In the second step, generalized least squares was applied and the estimated $p$ for each MSA used to remove the autocorrelation. ${ }^{4}$ It is interesting to note that after adjusting for autocorrelation, the statistically significant coefficients do not show extreme variation across property types. This appears reasonable, given that according to Exhibit 2, cap rates for the different property types display similar movements during the period studied.

The results shown in Exhibit 3 strongly indicate that real estate cap rates are influenced by capital market returns. Summing the coefficients by property type for each return category provides a measure of how cap rates are affected by market returns. The coefficients in Exhibit 3 indicate that cap rates are positively related to both the cost of debt and equity capital as expected from the model shown in equation (8). The statistical significance of the equity spread coefficients is supportive of the role of CAPM in equation (8). The large $t$-values on the lagged variables further indicate that real estate markets do not adjust quickly to capital market changes. The kind of lagged adjustment found here is suggestive of the inefficiencies in real estate markets. Our evidence on this issue is consistent with previous findings by Evans (1990)..$^{5}$

\section{Conclusions}

This paper formulates a model of real estate cap rates that is derived from traditional finance literature, drawing on WACC and CAPM. The model suggests that cap rates are determined by required returns in the debt and equity markets. Estimates of the model reveal that cap rates are strongly related to capital market returns, as predicted by the model. But the relation involves significant adjustment lags and market relationships vary significantly across local areas. Our findings confirm the widely held expectation that real estate markets are inefficient markets that are not completely integrated with the national capital market.

\section{Notes}

1Brueggeman and Fisher (1993: 442) use the band of investment approach in developing the capitalization rate. The approach shown is based upon the weighted average cost of capital conceptualization assuming no income growth. The weights for mortgage and equity capital are based upon initial loan-to-value and equity-to-value ratios. As in the stock and bond markets, the initial funding of property with mortgage and equity capital is accomplished in a competitive capital market. Therefore, inputs to the band of investment approach are based on market weights. The WACC equation is also based upon market value, using replacement cost. It is the market value of the project funded using debt and equity from the capital markets consistent with maintaining a long-run target debt-to-value ratio (Copeland and Weston, 1988: 447). At any point in time, it would be advantageous for both a firm and property investor to sustain the optimal capital structure (minimize the WACC). Realistically, to maintain the optimal structure, firms may fund some projects with debt and others with equity instead of issuing both for each project. Similarly, property investors would acquire new debt in proportion to changes in the equity value of property.

2Although the regression coefficient for the debt spread, /31, would have theoretical boundaries of $(0,1)$, the actual coefficient value may lie outside this range. One reason is that in the absence of 
knowing the actual debt type of each property and its maturity, we used a general proxy for risky debt. Second, informational inefficiencies may create lagged effects that complicate the interpretation of $\beta$, as a measure of the market-weighted loan/value ratio. The coefficient for the equity spread $\left(\beta_{4}\right)$ captures the product of the property beta and the equity weighting (one minus the loan-to-value ratio). An estimate of the equity weighting in isolation requires an estimation of the covariance of net operating income for the property with stock market returns, which cannot be accurately estimated from the cap rate data source used for this study.

3 A White test reveals no heteroscedasticity present in the variance-covariance matrix of the OLS estimator for all regressions that causes it to differ from the usual formula. In addition, we test for separate slope coefficients for the market spread variables among the various MSAs, and find no evidence that the slopes for debt and equity spreads vary by MSA.

4 LIMDEP 6.0 includes an autocorrelation procedure for panel data. The procedure of eliminating autocorrelation in panel data is detailed in Hsiao (1986), and is consistent with the LIMDEP method (Greene, 1992, 1990).

${ }_{5}$ The price/earnings ratio used by Evans (1990) and the total market return used in this study are related. Suppose Po is the level of the S\&P index in year $0, \mathrm{P} 1$ is the level of the index in period $1, E$ is earnings per share to common shareholders, and $d$ is the dividend payout ratio. The total

return on the market $(r M)$ can then be stated as:

$$
r_{M}=\left(\left(P_{1}-P_{0}\right)+d^{*} E\right) / P_{0} \text {. }
$$

If $d=1$ and the price change in the index is zero, $r M$ equals the earnings/price ratio.

\section{References}

Ambrose, B. W. and H. 0. Nourse, Factors Influencing Capitalization Rates, Journal of Real Estate Research, 1993, 8:2, 221-37.

Brealey, R. A. and S. C. Myers, Principles of Corporate Finance, New York, N.Y.: McGraw-Hill, fourth edition 1991.

Brueggeman, W. B. and J. D. Fisher, Real Estate Finance and Investments, Homewood, Ill.: Irwin, ninth edition 1993.

Copeland, T. E. and J. F. Weston, Financial Theory and Corporate Policy, Reading, Mass.: AddisonWesley, third edition 1988.

Ellwood, L. W, Ellwood Tables, Chicago, Ill.: American Institute of Real Estate Appraisers, third edition 1970.

Evans, R. D., A Transfer Function Analysis of Real Estate Capitalization Rates, Journal of Real Estate Research, 1990, 5:3, 371-80.

Fisher, J. D. and G. H. Lentz, Tax Reform and the Value of Real Estate Income Property, AREUEA Journal, 1986, 14:2, 287-315.

and J. J. Stern, Tax Incentives for Investment in Nonresidential Real Estate, National Tax Journal, March 1984, 69-87.

Froland, C., What Determines Cap Rates on Real Estate, Journal of Portfolio Management, 1987, 13, 77-83.

Greene, W H., Econometric Analysis, New York: MacMillan, 1990.

, LIMDEP Version 6.0 User's Manual and Reference Guide, New York: Econometric

Software, 1992.

Grissom, T. V., D. Hartzell and C. H. Lui, An Approach to Industrial Real Estate Market Segmentation and Valuation Using the Arbitrage Pricing Paradigm, AREUEA Journal, 1987, 15:3, 199-219. 
Guntermann, K. L. and R. L. Smith, Deviation of Cost of Capital and Equity Rates from Market Data, AREUEA Journal, 1987, 15:2, 98-109.

Hsiao, C., Analysis of Panel Data, Cambridge, U.K.: Cambridge University Press, 1986.

Modigliani, E and M. H. Miller, The Cost of Capital, Corporation Finance and the Theory of Investment, American Economic Review, 1958, 48:3, 261-97.

Nourse, H. 0., The "Cap Rate," 1966-1984: A Test of the Impact of Income Tax Changes on Income Property, Land Economics, 1987, 63:2, 147-52.

Ricks, R. B., Imputed Equity Returns on Real Estate Financed with Life Insurance Company Loans, Journal of Finance, 1969, 24:5, 921-37.

Sharpe, W. F, Capital Asset Prices: A Theory of Market Equilibrium Under Conditions of Risk, Journal of Finance, 1964, 19:3, 425-42.

Sirmans, C. F. and J. R. Webb, Expected Equity Returns on Real Estate Financed with Life Insurance Company Loans: 1967-1977, AREUEA Journal, 1980, 8:2, 218-28. , Investment Yields in the Money, Capital and Real Estate Markets: A Comparative Analysis for 1951-1976, Real Estate Appraiser and Analyst, 1978, 44:6, 40-46.

Wang, K., T. V. Grissom and S. G. Chan, The Functional Relationship and Use of Going-in and Going-out Capitalization Rates, Journal of Real Estate Research, 1990, 5:2, 231-45. 